\title{
Anxiolytic drug targets: beyond the usual suspects
}

\author{
Joshua A. Gordon \\ Center for Neurobiology and Behavior, Department of Psychiatry, Columbia University, New York, New York, USA \\ New York State Psychiatric Institute, New York, New York, USA
}

J. Clin. Invest. 110:915-917 (2002). doi:10.1172/JCI200216846.

Individuals suffering from anxiety experience an unpleasant emotional state defined by psychological and physiological responses to the anticipation of real or imagined danger. Physical manifestations include increased heart rate, altered respiration, sweating, trembling and fatigue, while psychological concomitants include feelings of powerlessness, apprehension, and potential danger. Many effective treatments for anxiety target the primary inhibitory neurotransmitter, $\gamma$-aminobutyrate (GABA). Within the brain, there are two principal subtypes of GABA receptor complexes: $\mathrm{GABA}_{\mathrm{A}}$ and $\mathrm{GABA}_{\mathrm{B}}$. The subunits of the pentameric $\mathrm{GABA}_{\mathrm{A}}$ receptor form a tight group enclosing a chloride channel whereby GABA activation induces channel opening and subsequent influx of chloride ions $\left(\mathrm{Cl}^{-}\right)$into the intracellular medium. The increase in negative charge causes neuronal membrane hyperpolarization and a resultant inhibition of neurotransmitter release. In this way, GABA agonists can induce anxiolysis, sleep, and anesthesia.

\section{Treatment of anxiety disorders: modulating $\mathrm{GABA}_{\mathrm{A}}$ receptors}

Allosteric modulators of $\mathrm{GABA}_{\mathrm{A}}$ receptors have anxiolytic, sedative/hypnotic, and anesthetic properties, presumably derived from this ability to

\footnotetext{
Address correspondence to: Joshua A. Gordon, Center for Neurobiology and Behavior, Columbia University, New York State Psychiatric Institute, 1051 Riverside Drive, Unit 87, New York, New York 10032, USA. Phone: (212) 543-5309; Fax: (212) 543-5074;

E-mail:jg343@columbia.edu. Conflict of interest: No conflict of interest has been declared.

Nonstandard abbreviations used: $\gamma$-aminobutyrate (GABA); chloride ions $\left(\mathrm{Cl}^{-}\right)$; protein kinase $\mathrm{C} \varepsilon(\mathrm{PKC} \varepsilon)$.
}

enhance inhibitory neurotransmission through facilitation of receptor function. Benzodiazepines and barbiturates have been utilized with great success as anxiolytics in humans, but their use is limited due to their addictive potential and sedating side effects. An additional class of $\mathrm{GABA}_{\mathrm{A}}$ receptor modulators, the neurosteroids, have seen limited use as anesthetics, and have been proposed as potential therapeutic agents for anxiety disorders. However, the poor bioavailability, solubility, and side effect profiles of these compounds has limited their application in humans. The search for more practical anxiolytics relies on the identification of novel targets impinging upon this $\mathrm{GABA}_{A}$ receptor-mediated pathway.

In this issue of the JCI, Hodge and colleagues suggest such a target (1). Combining genetic, behavioral, and pharmacological levels of analysis, the authors demonstrate that the $\mathrm{GABA}_{\mathrm{A}}$ modulators themselves have a modulator: the $\varepsilon$ isozyme of protein kinase $\mathrm{C}$ (PKCE). They present an intriguing link between $\mathrm{PKC} \varepsilon$, anxiety, and endogenous allosteric enhancers of $\mathrm{GABA}_{A}$ function, suggesting that the clinical benefits of modulating $\mathrm{GABA}_{\mathrm{A}}$ receptor activity might be realized by targeting this kinase.

\section{PKCE-deficient mice, neurosteroids and anxiety}

In the current article (1), Hodge et al. present further characterization of a line of knockout mice lacking PKCE. As reported previously, these mice are characterized by enhanced sensitivity to $\mathrm{GABA}_{\mathrm{A}}$ receptor allosteric modulators, including ethanol, benzodiazepines, and barbiturates (2). The authors now extend these observations to include the endogenous
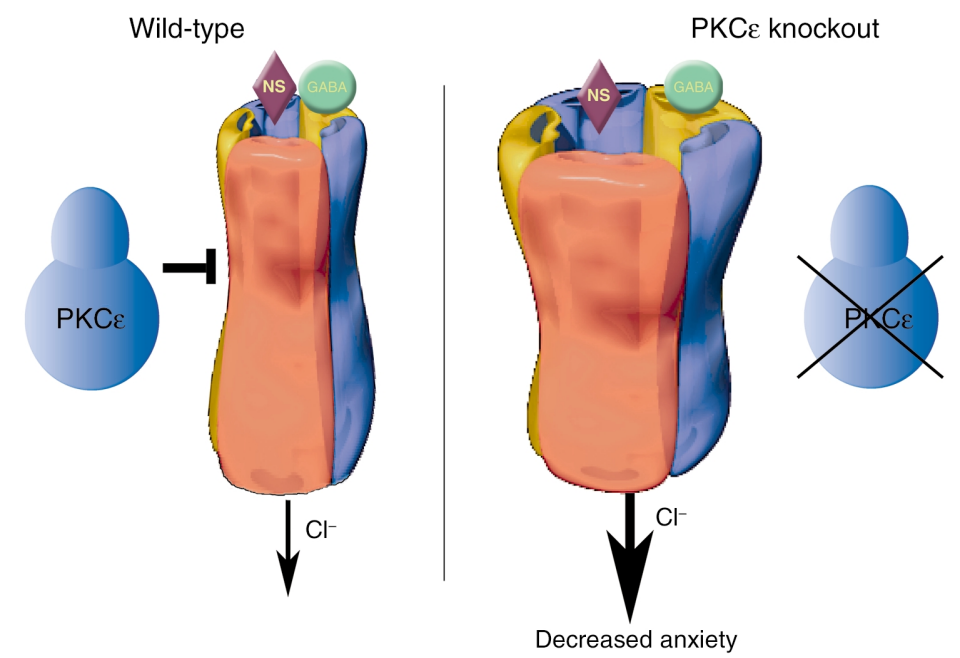

Figure 1

In PKCE knockouts, the $\mathrm{GABA}_{\mathrm{A}}$ receptor has enhanced sensitivity to neurosteroids, resulting in increased $\mathrm{Cl}^{-}$conductance when activated by both GABA and endogenous neurosteroids. PKC $\varepsilon$ knockouts also have reduced anxiety-like behavior, suggesting that PKC $\varepsilon$ deficiency leads to decreased anxiety by making the $\mathrm{GABA}_{\mathrm{A}}$ receptor more sensitive to the anxiolytic action of endogenous compounds such as neurosteroids. 
neurosteroids, allopregnanolone and pregnanolone, which routinely enhance $G_{A B A}$ receptor activity and are synthesized by both neurons and glia (3). In PKCE knockout mice, these compounds increased muscimol-stimulated $\mathrm{Cl}^{-}$uptake from cortical microsacs to a greater degree than in wild-type mice (Figure 1). Behaviorally, pregnanolone induced a more prolonged loss of the righting reflex in the PKCE mutants, demonstrating greater sensitivity to the anesthetic effect in these animals (1).

The PKCE knockout mice also had reduced levels of anxiety-like behavior in the elevated plus maze and open field test, two well-characterized rodent models of anxiety. Intriguingly, doses of the $\mathrm{GABA}_{\mathrm{A}}$ receptor antagonist bicuculline, that had no effect in wild-type mice, restored anxiety-like behavior in the PKCE mutants, suggesting that increased $\mathrm{GABA}_{\mathrm{A}}$ receptor activity, as opposed to another, uncharacterized effect of the gene deletion, is responsible for the behavioral phenotype (1). A parsimonious, though hardly conclusive, explanation of these results is that increased sensitivity to an endogenous allosteric modulator results in increased $\mathrm{GABA}_{\mathrm{A}}$ receptor activity, thereby decreasing anxiety-like behaviors.

Neurosteroids are attractive candidates for the role of endogenous modulators. Available data suggest their effect on $\mathrm{GABA}_{\mathrm{A}}$ receptor function is most likely responsible for the significant behavioral traits observed following their application. Neurosteroids that enhance $\mathrm{GABA}_{\mathrm{A}}$ receptor function have anxiolytic-like properties in animal models, including the elevated plus maze (4). Neurosteroids that inhibit $\mathrm{GABA}_{\mathrm{A}}$ receptor function act in an anxiogenic fashion $(3,5)$. Picrotoxin, which blocks $\mathrm{GABA}_{\mathrm{A}}$ receptors, generally prevents the anxiety-related effects of the neurosteroids (3). Recently, abnormal neurosteroid levels have been found in patients suffering from anxiety and depressive disorders, suggesting direct relevance to human psychiatric illness $(6,7)$. Unfortunately, attempts to capitalize on these effects by developing clinically useful synthetic neurosteroids have met with minimal success (8).

PKCE and $\mathrm{GABA}_{\mathrm{A}}$ receptor sensitivity

Given that allosteric enhancers of $\mathrm{GABA}_{\mathrm{A}}$ receptor activity have proven clinically problematic, the finding that PKC $\varepsilon$ deficiency yields anxiolytic-like results is promising. Nonetheless, caution must be exercised in the interpretation of results from constitutive knockout experiments. These mice lack the protein kinase throughout development, leaving open the possibility that $\mathrm{PKC \varepsilon}$ deficiency causes an increase in $\mathrm{GABA}_{\mathrm{A}}$ receptor sensitivity to allosteric modulators through a developmental or compensatory process. Application of PKC $\varepsilon$ antagonists in the adult, therefore, might not yield the same result. Indeed, direct activation of PKC by phorbol esters has been shown to increase $\mathrm{GABA}_{\mathrm{A}}$ receptor sensitivity to neurosteroids (9). This result is the opposite of what would be expected given the data presented by Hodge et al. (1), and would suggest that PKC deficiency should decrease, not increase, $\mathrm{GABA}_{\mathrm{A}}$ receptor sensitivity to these compounds.

Fortunately, existing data suggests an alternative hypothesis for the discrepancy between the effects of the PKCE knockout and the effects of phorbol ester-induced activation. The authors have previously shown that a PKCE-specific translocation inhibitor peptide (10) induces a similar increase in $G_{A B A}$ receptor sensitivity to allosteric modulation in wild-type but not PKC $\varepsilon$ knockout mice (2). Similar effects of acute, specific inhibition of $\mathrm{PKC} \varepsilon$ on $\mathrm{GABA}_{\mathrm{A}}$ receptor activity have also been demonstrated in cardiac myocytes (11). Eliminating the kinase throughout development appears, therefore, to have the same effects as acutely antagonizing PKCE function. The data argue that the phorbol ester experiment, by inducing activation of all PKC family members, obscures the specific role of the PKCE isozyme.

\section{Identifying the mechanism}

How might PKCE deficiency enhance allosteric modulation of the $\mathrm{GABA}_{\mathrm{A}}$ receptor? A quite general mechanism must be required, as the sites of action of neurosteroids, barbiturates, and benzodiazepines on the $\mathrm{GABA}_{\mathrm{A}}$ receptor are distinct (8). Although it appears that neurosteroids are capable of modulating $\mathrm{GABA}_{\mathrm{A}}$ receptors with a variety of subunit compositions (8), a recent report suggests that the $\delta$-subunit may be required for their anxiolytic and physiological effects (12). In contrast, the benzodiazepine binding site, for example, involves the $\alpha$ and $\gamma$ subunits (13). In order to facilitate the actions of different modulators acting at disparate sites, PKCE must interact with diverse subunits. The most obvious candidate mechanism for such an interaction is phosphorylation - perhaps the kinase phosphorylates numerous sites across the various receptor subunits. The authors point out, however, that phosphorylation at known PKC-mediated sites is not altered in the PKCE knockouts (2). Further research into the precise mechanisms by which PKCE and neurosteroids modulate $\mathrm{GABA}_{\mathrm{A}}$ receptors is clearly needed to further understand the nature of the interaction.

\section{PKC\&: Possible target for anxiolytic therapy?}

The exciting take-home message from Hodge et al., is the idea that PKCe should be considered as a potential target for anxiolytic therapy (1). All classes of allosteric modulators of $\mathrm{GABA}_{\mathrm{A}}$ receptor activity have been demonstrated to be effective anxiolytics, in humans and/or animal models (14). The current work demonstrates that: (a) PKCE deficiency results in enhanced $\mathrm{GABA}_{\mathrm{A}}$ receptor sensitivity to members of each of these classes of allosteric modulators, (b) this enhanced sensitivity is accompanied by decreased levels of anxiety-like behaviors, and (c) these behaviors can be normalized by mild $\mathrm{GABA}_{\mathrm{A}}$ receptor blockade. Further work is necessary to prove a causal relationship between enhanced modulator sensitivity (as opposed to some other, yet unidentified, alteration in GABAergic neurotransmission) and the behavioral effect. It is important to identify which endogenous modulators, if any, are required for the behavioral effect. These caveats notwithstanding, it is attractive to imagine that PKCE blockade would result in anxiolysis by making our brains more sensitive to our own endogenous anxiolytics.

\footnotetext{
1. Hodge, C.W., et al. 2002. Decreased anxiety-like behavior, reduced stress hormones, and neurosteroid supersenstivity in mice lacking protein kinase CE. J. Clin. Invest. 110:1003-1010 doi:10.1172/JCI200215903.

2. Hodge, C.W., et al. 1999. Supersensitivity to allosteric $\mathrm{GABA}_{\mathrm{A}}$ receptor modulators and alcohol in mice lacking PKCE. Nature Neurosci. 2:997-1002.

3. Baulieu, E.E., Robel, P., and Schumacher, M 2001. Neurosteroids: beginning of the story. Int Rev. Neurobiol. 46:1-32.
} 
4. Engel, S.R., and Grant, K.A., 2001. Neurosteroids and behavior. Int. Rev. Neurobiol. 46:321-348.

5. Melchior, C.L., and Ritzmann, R.F., 1994. Dehydroepiandrosterone is an anxiolytic in mice on the plus maze. Pharmacol. Biochem. Behav. 47:437-441.

6. Spivak, B., et al. 2000. Elevated circulatory level of $\operatorname{GABA}(\mathrm{A})$ - antagonistic neurosteroids in patients with combat-related post-traumatic stress disorder. Psychol. Med. 30:1227-1231.

7. Bicikova, M., Tallova, J., Hill, M., Krausova, Z., and Hampl, R. 2000. Serum concentrations of some neuroactive steroids in women suffering from mixed anxiety-depressive disorder. Neurochem. Res. 25:1623-1627.
8. Lambert, J.J., Belelli, D., Harney, S.C., Peters, J.A., and Frenguelli, B.G. 2001. Modulation of native and recombinant $\mathrm{GABA}_{\mathrm{A}}$ receptors by endogenous and synthetic neuroactive steroids. Brain Res. Rev. 37:68-80.

9. Leidenheimer, N.J., and Chapell, R. 1997. Effects of $\mathrm{PKC}$ activation and receptor desensitization on neurosteroid modulation of $\mathrm{GABA}_{\mathrm{A}}$ receptors. Mol. Brain Res. 52:173-181.

10. Yedovitzky, M., et al. 1997. Translocation inhibitors define specificity of protein kinase $\mathrm{C}$ isoenzymes in pancreatic $\beta$-cells. J. Biol. Chem. 272:1417-1420.

11. Zhang, H.Y., et al. 2002. $\mathrm{H}(2) \mathrm{O}(2)$ opens mitochondrial K(ATP) channels and inhibits GABA receptors via protein kinase $\mathrm{C}$-epsilon in car- diomyocytes. Am. J. Physiol. Heart. Circ. Physiol. 282:H1395-H1403.

12. Mihalek, R.M., et al. 1999. Attenuated sensitivity to neuroactive steroids in gamma-aminobutyrate type A receptor delta subunit knockout mice. Proc. Natl. Acad. Sci. USA. 96:12905-12910.

13. Sigel, E., and Buhr, A. 1997. The benzodiazepine binding site of $\mathrm{GABA}_{\mathrm{A}}$ receptors. Trends Pharmacol. Sci. 18:425-429.

14. Gorman, J.M., Kent, J.M., and Coplan, J.D. 2002. Current and emerging therapeutics of anxiety and stress disorders. In Neuropsychopharmacology, $5^{\text {th }}$ generation of progress. K.L. Davis, D. Charney, J.T. Coyle, and C. Nemeroff, editors. Lippincott Williams and Wilkins. Philadelphia, Pennsylvania, USA. 967-980. 